\title{
HOW APPLICABLE IS THE IDEA OF DEEP ECOLOGY IN THE AFRICAN CONTEXT?
}

DOI: http://dx.doi.org/10.4314/ft.v4i1.1

\author{
Fainos MANGENA PhD \\ Department of Religious Studies, Classics and Philosophy, University of Zimbabwe
}

\begin{abstract}
In this paper, I outlined and discussed the idea of deep ecology as defended by Arne Næss (1973) as well as Bill Devall and George Sessions (1985). I especially looked at how deep ecology has responded to the dominant view in ecological ethics, especially its attendant theory - anthropocentrism or homo-centrism or simply the reason-based account - which I outlined and explained in the first section of this paper. In the final analysis, I looked at the feasibility (or lack thereof) of applying deep ecology in Sub-Saharan African ecological contexts focusing particularly on the Shona ecological matrix of Zimbabwe. My intention was to answer the question: How applicable is the idea of deep ecology in the African context? Having reviewed Zimbabwean literature, I came to the conclusion that the Shona enviro nment had a different form of deep ecology that was not only anchored on spirituality but that it also interpreted cosmology and ecology from a communitarian viewpoint.
\end{abstract}

Keywords: Deep ecology, the dominant view, anthropocentrism, spirituality, the human world, the non-human world.

\section{Introduction}

This paper looks at the feasibility (or lack thereof) of applying the idea of deep ecology in non-Western ecological contexts such as the ecological context of the Shona people of Zimbabwe ${ }^{1}$. It begins by highlighting the major assumptions of the dominant worldview as well as its major weaknesses. The dominant view states that nature exists to serve humanity and that ecology must be preserved solely for the benefit of present and future generations of human beings. What this amounts to is that human beings have intrinsic value compared to non-human beings which have only instrumental value. Defenders of the dominant view are called anthropocentrists or homo-centrists. The major weakness of the dominant view is that it does not consider human beings to be part of nature, a position which is problematic.

The paper then proceeds to discuss the idea of deep ecology as a response to the dominant worldview. To this end, Arne Næss, the one who coined the term deep ecology, defines deep ecology as that deeper questioning about human life, society and nature which goes beyond the so-called factual scientific level to the level of self and earth wisdom (NÆSS cited in MACKINNON 1998, 358). For Næss, the

$\sigma^{1}$ The Shona people constitute the largest tribal grouping in Zimbabwe and their language is quite widespread since it has six dialects namely, Karanga, Korekore, Kalanga, Zezuru, Manyika and Ndau. 
foundations of deep ecology are the basic intuitions and experiencing of ourselves and nature which comprise ecological consciousness (1998, 358). Deep ecology differs from the dominant view in that it considers nature to be at par with human beings and best summed up in eight basic principles which shall be outlined and explained later in the paper (DEVALL and SESSIONS cited in MACKINNON 1998, 359). Having identified the problems associated with Næss and Sessions' deep ecology, the paper argues that this version of deep ecology cannot be applied in contexts that are non-Western particularly the ecological context of the Shona people of Zimbabwe where the idea of ecology has both cultural and spiritual connotations.

Besides, Næss and Sessions' deep ecology appeal more to cultures that are individualistic and yet the Shona culture is communitarian. I conclude my paper with a summative table on the dissimilarities between Næss and Sessions' deep ecology and the Shona ecological version of deep ecology, I begin my account by discussing the major assumptions of the dominant worldview, focusing particularly on this view as defended by members of the anthropocentric or homocentric or reason based school.

\section{The Dominant Worldview}

Briefly put, the dominant worldview ${ }^{2}$ in ecological ethics holds that nature exists for the service of humanity. It maintains that the environment ${ }^{3}$ and its content have instrumental value and must be utilized for the benefit of both present and future generations of human beings. Defenders of the dominant worldview belie ve that only human beings have intrinsic value because they have the faculty of reason which sets them apart from other beings. According to the anthropocentric or homocentric school, human beings because of their ability to use reason, have intrinsic wor th because they confront choices that are purely moral; they lay down moral laws for others and for themselves (COHEN 1986, 94-95). From this viewpoint, reason is used as a criterion to confer moral status to human beings while at the same time denying the same to non-human beings.

As a result of this thinking, defenders of the dominant worldview, especially members of the anthropocentric school, see nothing wrong with the cruel treatment of non-human animals unless such treatment would lead to bad consequences for

\footnotetext{
${ }^{2}$ To the question: Why is it called the dominant view? I wo uld say, it is called the dominant view probably because it has many defenders dating from Socrates to the present generation of environmental philosophers. The other reason is that it is a position defended by human beings and it is about human beings superior place in the environment.

3 When defining ecological ethics and environmental ethics, it is important to begin by distinguishing between ecology and the environment. Thus, while ecology deals with the Jrelationship between organisms and their environment, the environment is basically the Doprganisms' surroundings (Rudeen, 2009). Given this background, the paper would therefore $\widetilde{\sigma}$ define ecological ethics as the ethics that guide organisms in their everyday encounter with the environment and men while environmental ethics are defined simply as the ethics that guide men as he relates with the environment.
} 
human beings (MAPPES and ZEMBATY 1997, 459). Kant puts it aptly when he observes thus: "cruelty towards a dog might encourage a person to develop a character which would be desensitized to cruelty towards human beings" (KANT cited in INFIELD 1963, 241). J. B Callicot $(1980,325)$, one of the avid defenders of the anthropocentric school, remarks that "only human beings are able to give values to the eco-system and this means that all intrinsic value is grounded in human beings and projected onto the natural object that excites the value." While this thinking is popular among anthropocentrists in the West and has found an audience there, it also has influenced the thinking of some African people especially some Zimbabweans.

This is so because Zimbabwe's new constitution is anthropocentric when it comes to the issue of environmental rights and privileges (cf. MANGENA 2014, 225-226). For instance, Chapter 4 of Zimbabwe's new constitution entitled: Declaration of Rights, section 73 , page 46 categorically states that:

Every person has the right:

(a) To an environment that is not harmful to their health or well being and

(b) To have the environment protected for the benefit of present and future generations through reasonable legislative and other measures that,

(i) Prevent pollution and ecological degradation;

(ii) Promote conservation and,

(iii) Secure ecologically sustainable development and use of natural resources while promoting economic and social development (MANGENA 2014, 226).

Although item $b$ (iii) does seem to be silent about the need to have the environment protected for the benefit of human beings, the presence of the words; sustainable, economic and social development, point to some deeply entrenched anthropocentrism. These are not the kind of words used to describe activities in the non-human world.

Elsewhere, I have argued that African attitudes to the environment are different from those of the Westerners in that the former regard human beings as part of nature while the latter view the same as separated from nature. Thus, the former consider human beings to be related to non-human beings through the ideas of totemism and spiritualism (MANGENA 2013, 33). Other Zimbabwean scholars, whose works I have reviewed, have also provided a corpus of literature that $r$ eflects on the positive cultural attitudes to nature by the Shona people (MASAKA and CHEMHURU 2010; MUROVE 2007 and TARINGA 2014). The question now is; if this is generally what Zimbabweans think about the relationship between human beings and the environment, then what explains the anthropocentric traits found in the country's new constitution? Isn't there too much romanticization of culture here?

Probably, part of the answer to these two questions would be to say that

There is a difference between what is ideal and what is obtaining in any given society coand at any given time. My point is that although the Zimbabwean constitution is Zanthropocentric, it may not necessarily be a reflection of how most Zimbabweans view nature. That Zimbabweans revere nature is not a matter of ideation; it is a 
matter of fact. This is expressed in Zimbabwe's folk tales, proverbs and riddles. For instance, in Zimbabwean folk tales, animals like the hare and the baboon are personified, with the hare being given the designation muzukuru (nephew) and the baboon being given the designation sekuru (uncle). While the former is portrayed as clever or intelligent; the latter as portrayed is foolish. This personification, no doubt, shows the cordial relationship between men and nature.

Even the idea of totemism that motivates human beings to want to appropriate animal traits like courage, humility and cunningness shows that Zimbabweans are generally not anthropocentric in character. Vaera Shumba (Those who belong to the Lion totem), for instance, feel respected when called by their totems: Makadiiko Shumba? (How are you Lion?) or Makadiiko Nzou? (How are you Elephant?) Having said that, one can argue that Zimbabwe's new constitution could be a product of the legacy of colonialism where some people tend to think that what is European is more civilized than what is African. ${ }^{4}$ In the next section, I define, outline and discuss the major assumptions of deep ecology as it responds to the dominant view in environmental ethics.

\section{The Assumptions of Deep Ecology}

To begin with, the term deep ecology was coined by Arne Næss in his 1973 article entitled: The Shallow and the Deep, Long Range Ecology Movements (in MACKINNON 1998, 358). In this article, Næss defines deep ecology as that deeper questioning about human life, society and nature which goes beyond the so-called factual scientific level to the level of self and earth wisdom $(1998,358)$. For Næss, the foundations of deep ecology were the basic intuitions and experiencing of ourselves and nature which comprise ecological consciousness $(1998,358)$. What Næss is probably suggesting here is that human beings will only be in a position to understand and appreciate nature if they can avoid seeing it as something that is there to solve their problems.

Thus, deep ecology as a form of ecological consciousness differs greatly from the dominant worldview that considers nature to be at a lower level than the human being. Such a world view sees men as the measure of all things (to borrow Protagoras' words). As Bill Devall and George Sessions (in MACKINNON 1998, 358) put it in agreement with the above submission:

Ecological consciousness and deep ecology are in sharp contrast with the dominant world view...which regards humans as isolated and fundamentally separate from the rest of nature, as superior to, and in charge of, the rest of creation.

I will expand this point later as I look at the ontological import of the idea of deep ecology in non-Western cultures. 
Devall and Sessions maintain that "for thousands of years Western culture has been too intoxicated with the idea of dominance: with dominance of humans over nature, masculine over feminine, wealthy and powerful over the poor, with the dominance of the West over non-Western cultures" $(1998,358)$. For Devall and Sessions, deep ecology allows us to see through these erroneous and dangerous illusions (1998, 358). Devall and Sessions maintain that for deep ecology, the study of our place in the earth household includes the study of ourselves as part of the organic whole (1998: 359). The point that Devall and Sessions are making is that human beings do not lie outside of nature they are part of it. They present the following as the eight basic principles of deep ecology:

1. The well-being and flourishing of human and non-human life on earth have value in themselves (synonyms: intrinsic value, inherent value). These values are independent of the usefulness of the non-human world for human purposes.

2. Richness and diversity of life forms contribute to the realization of these values and are also values in themselves.

3. Humans have no right to reduce this richness and diversity except to satisfy vital needs.

4. The flourishing of human life and cultures is compatible with a substantial decrease of the human population. The flourishing of non-human life requires such a decrease.

5. Present human interference with the non-human world is excessive and the situation is rapidly worsening.

6. Policies must therefore be changed. These policies affect basic economic, technological and ideological structures. The resulting state of affairs will be deeply different from the present.

7. The ideological change is mainly that of appreciating life quality (dwelling in situations of inherent value) rather than adhering to an increasingly higher standard of living. There will be a profound awareness of the difference between big and great.

8. Those who subscribe to the foregoing points have an obligation directly or indirectly to try to implement the necessary changes (1998: 359).

\section{Næss' and Sessions' Explanation of the Basic Principles}

For Næss and Sessions, basic principle 1 refers to the biosphere or more accurately to the ecosphere as a whole and this includes individuals, species, populations, habitat as well as human and non-human cultures $(1998,361)$. Their point is that there is need for a deep concern and respect about the ecosphere as a whole. The y use the term life in a non-technical sense to refer also to inanimate objects like rivers,

$\checkmark$ landscapes and ecosystems $(1998,361)$. By inherent value, they mean that something ohas worth even if conscious beings have no awareness, interests and appreciation of $\widetilde{\Omega}_{\text {it }}(1998,361)$. Commenting on basic principle 2, Næss and Sessions argue that the so called simple, lower or primitive species of plants and animals contribute 
essentially to the richness and diversity of life. Næss and Sessions notes that these have value in themselves and are not only steps toward the so-called higher or rational life forms $(1998,361)$.

Coming to basic principle 3, Næss and Sessions postulate that the term vital need is left deliberately unclarified to allow for considerable latitude in judgment $(1998,362)$. For Næss and Sessions when defining vital needs, it is important to consider differences in weather patterns as well as differences in societal structures especially as they exist at present. They give the example of Eskimos who, according to them, still need snowmobiles to satisfy their vital needs $(1998,362)$. For them, people in the materially richest countries cannot be expected to reduce their excessive interference with the nonhuman world to a moderate level overnight. If ever this will happen, it will take time $(1998,362)$.

In their explanation of basic principle 4 Næss and Sessions quoted from the report by the United Nations Fund for Population Activities which said that high human population growth rates in many developing countries were diminishing the quality of life for many millions of people in the 1970s and 80s. They used this to justify their claim that the quality of both human and non-human life had a correlation with population growth, meaning that an increase in population had a negative impact on the quality of life while the reverse was equally true. On basic principle 5, Næss and Sessions observe that the slogan "non-interference" does not imply that humans should not modify some ecosystems as do other species. Humans have modified the earth and will probably continue to do so. At issue is the nature and extent of such interference $(1998,362)$.

Næss and Sessions explain basic principle 6 by observing the detrimental effects of the idea of economic growth especially its incompatibility with basic principles 1-5 $(1998,362)$. Their point is that there is only "a faint resemblance between ideal sustainable forms of economic growth and present policies of the industrial societies and to them "sustainable" still means "sustainable in relation to humans" $(1998,362)$. It would seem, as Næss and Sessions argue, that governments are not interested in deep ecological issues that ensure the protection of the nonhuman world, all they are interested in seeing is the gr owth of their economies. Næss and Sessions therefore urge governments to think globally, and to act locally with regard to ecological issues $(1998,362)$.

Coming to basic principles 7 and 8 , Næss and Sessions believe that the idea of life quality cannot only be restricted to human life; it must also be extended to other life forms as both the human world and the non-human world have inherent value. In fact, they argue that while for some economists, the idea of life quality is vague; For Næss and Sessions, it is the non quantitative nature of the term that is vague as it is difficult to quantify adequately what is important for the quality of life as discussed here $(1998,363)$. On basic principle 8, although Næss and Sessions Eorgue that those who subscribe to the foregoing points have an obligation to try and a implement these changes, they do admit that people can have different opinions about priorities $(1998,363)$. 


\section{My Analysis of the Eight Basic Principles of Deep Ecology}

In basic principle 1, Næss and Sessions argue that both human beings and nonhuman beings have intrinsic value in themselves. I have no problem with this argument but my problem comes when they argue these values are independent of the usefulness of the non-human world for human purposes. This second part of the principle, to me, takes away the intrinsic or inherent value of the non-human world thereby giving it instrumental value. Thus, the principle seems to contradict itself. Besides, there is no force that ensures that the human world will not violate this principle, something like a law, or an invisible agent.

With regard to basic principle 2, which states that "richness and diversity of life forms contribute to the realization of these values and are also values in themselves," Næss and Sessions have not clearly demonstrated how richness and diversity of life forms can give intrinsic or inherent value to both human beings and non-human beings. Besides, this principle seems, to me, to contradict the second part of the first principle which considers the non-human world to have instrumental value. As I have observed earlier, there does not seem to be a closer relationship between the human world and the non-human world, that is, nothing brings the two together. But whichever way one may want to look at it, deep ecologists are committed to seeing human beings treating the environment with utmost respect.

The third basic principle, just like the first, treats the non-human world as world that has instrumental value to the human world. This is notwithstanding the caution that Næss and Sessions make to the effect that human beings should not reduce the richness and diversity of nature. Besides, there is no attempt to define "vital needs" and to explain why it is important to have these needs satisfied at the expense of the non-human world. Even if these "vital needs" were to be explained, I also believe that the non-human world has vital needs which the human world should satisfy. It cannot be a one way traffic. While there is an element of commitment to seeing a society that respects the interests and needs of other life forms, this basic principle sounds anthropocentric.

Coming to the fourth and fifth basic principles combined, I do not know what Næss and Sessions mean when they say, "the flourishing of human life and cultures is compatible with a substantial decrease of the human population. The flourishing of non-human life requires such a decrease." This statement, to me, contradicts the first and third principles where part of the emphasis is on having other life forms existing for the benefit of humanity. The questions that I have for them are: How is the human population to be reduced if everything should work to its advantage? How is this flouring compatible with a decrease in population? Fine, I hear their argument when they point out that an increase in both the human and nonhuman population has a negative impact on the quality of life of both but this needs $N_{0}$ to be further explained to show how best the human populations can be reduced, ¿ospecially given the fact that countries in Africa and other third world zones have

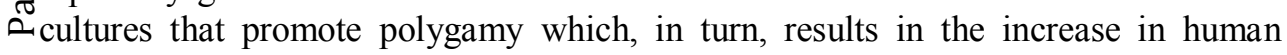
populations. 
In regard to the fifth principle, it is true that the human wor ld is interfering a lot with the non-human world and it is true that the situation is worsening. But part of the reason why the situation is worsening is because deep ecologists like Næss and Sessions - other than calling for the revision of the dominant view - have not really taken a position. They stand on the fence. My point is that we need to take a stand. If I were to take a Christian position, I would argue that human beings are only there to look after God's creatures; there are only Stewards and not Owners. If I were to take the position of African Religions, I would argue that Mwari (Creator God) through his Midzimu (ancestors) own both the human and non-human world and no human being has the right to ill-treat that which he does not own.

In regard to the sixth, seventh and eighth principles, I agree with Næss and Sessions that policies must be changed to ensure that the relationship between the human world and the non-human world should not be a horse and a rider relationship. The human world must appreciate the fact that its existence is to a larger extent dependent on the existence of the non-human world. The question: Who should initiate this change of policies? How represented will the non-human world be? Assuming that deep ecologists are very sincere and that they are committed to seeing this change of policy, my position is that they can initiate the change through advocacy, and that way the interests of the non-human world will be safeguarded. In order to have these policies implemented, there is need for some kind of force (law or some invisible agent) that will ensure that people have an obligation to be bound by them. Without this force, the efficacy of deep ecology will remain questionable. With this suggestion, I am not blind to the fact that deep ecologists may not have the power to enforce these laws; my point is that they can put more pressure to governments to implement these laws.

But can we say that the same kind of deep ecology that Næss, Devall and Sessions are talking about is the same kind of deep ecology that obtains in the Shona environment? While there can be no doubt that the idea of deep ecology exists in the Shona environment, there is doubt that it exists in the form that Næss, Devall and Sessions have explained above. Below, I explore the idea of deep ecology in the Shona environment.

\section{Another Corpus of Literature, another version of Deep Ecology}

The subject of ecology has been approached from different academic viewpoints in Zimbabwe but while none of the literature that I have reviewed has mentioned the phrase deep ecology, my research findings show that there has been a lot of reflection on this subject especially in the Shona environment. ${ }^{5}$ The literature that is key to this

Elsewhere, I have distinguished between the Western environment and the African environment by arguing that while the former is anthropocentric and non spiritual, the latter is non $\widetilde{\sigma}$ anthropocentric and spiritual (Mangena, 2013, 29-31). At this juncture, I wish to point out that the Shona environment, which I will explore in this section, is a sub-category of the African environment. 
debate was produced by, chief among others, Munamato Chemhuru and Dennis Masaka (2010), Zvakanyorwa Wilbert Sadomba (2014), Nisbert Taringa and Fainos Mangena (2015). Below, I review this literature, beginning with Chemhuru and Masaka (2010) who look at the place of taboos in the ecological matrix of the Shona people of Zimbabwe.

Chemhuru and Masaka (2010) provide some important insights into the Shona conceptualization of deep ecology. They argue that in order to protect the environment, the Shona make use of zviera (taboos) which fall in the category of avoidance rules. Taboos for Chemhuru and Masaka forbid members of the human community from performing certain actions such as eating some kinds of food, walking on or visiting sacred sites, cruelty to non-human animals and using nature's resources in an unsustainable manner $(2010,122)$. Chemhuru and Masaka give examples of these taboos in their argument. For instance, they pick the Shona taboo: Ukawetera mumvura unorwara nechirwere chehozhwe (If you urinate in water, you will catch Bilharzia) which is meant to dissuade people from abusing water sources, a behaviour which may lead to diseases $(2010,123)$. Besides, water is a habitat for other aquatic creatures, like fish, that must also be protected. Urine contains some components of nitrates that can cause the accumulation of algae, which is dangerous to aquatic life (2010: 127). Taboos are also used to promote the existence of plant life in water sources that may also be affected by unbecoming human behaviour.

Anyone who breaks this taboo becomes a threat to the health and wellbeing of other people and yet to fail to appreciate and respect the interests of other people is the worst thing that can ever happen to a Shona man or woman whose understanding of existence is communitarian (cf. MENKITI, 2006). Thus, whatever the individual does will not only affect others but it will also affect him. Ramose $(1999,50)$ argues that individuals can only meaningfully define their existence if they recognise that they need each other. Thus, the appropriation of taboo wisdom in Shona society is meant to promote harmony between individuals and their communities as well as between human communities and non-human communities.

Violators of these taboos are believed to invite the wrath of the spirit world and so every person would not want to be in a situation where he or she has to be punished severely for failing to observe certain rules. The punishments usually range from bad luck, disease, drought and even death $(2010,123)$. Thus, the observance of taboos promotes...life that fosters a desirable environmental ethic, while the breaking of taboos leads the moral agent to a vicious life that disregards not only the moral standing of the environment but also its sustainability $(2010,123)$. It is also important to note that in their appeal to the use of taboos, Chemhuru and Masaka $(2010,131)$ are also interested in the preservation of endangered species.

The following taboo helps to put this point into proper perspective: OUkauraya Shato mvura hainayi (If you kill a Python, there will be no rainfall). Their ogpoint is that the Python is among those animals that are slowly becoming extinct and 2 
so they need to be protected and so the taboo will help in protecting this endangered species. Human beings need rainfall for survival, with out it they will die. Given two choices, one that requires that they kill Pythons and experience droughts and another one that requires that they do not kill pythons and have enough rainfalls to sustain their livelihoods; they will choose the latter. So, the efficacy of this taboo is quite evident here. There are many other taboos that I could cite from Chemhuru and Masaka's study, but because of limited space and time, I will not be able to do just to that; instead, I will now look at the prospects of deriving deep ecology in Chemhuru and Masaka's submissions.

While Chemhuru and Chemhuru have not described this kind of ethic - in their own words -as deep ecology, there is a sense in which one can argue that theirs is a work of deep ecology that is spiritually anchored, for in their environmental ethic, Chemhuru and Masaka are not only appealing to taboos so as to have nonhuman animals protected but also to protect sacred sites as well as plants and vegetation. Although Masaka and Chemhuru have not really mentioned, by name, some of the sacred sites that need protection, I have no doubt in my mind that they refer to sacred sites like mountains (Buchwa and Inyangani), rivers (Chirorodziva) and rocks (Matonjeni/Zame) whose role and importance, I will explain shortly.

The idea of deep ecology also runs through Sadomba's 2014 essay which is published in a volume edited by CG Mararike entitled: Land: An Empowerment Asset for Africa: The Human Factor Perspective, published by the University of Zimbabwe Publications. In this essay, Sadomba $(2014,352)$ observes that indigenous Zimbabweans have a cosmology that is different from that of the Europeans. This cosmology, for Sadomba, is based on a philosophy that recognises the harmonious trinity of nature, society and the spirit world $(2014,352)$. These three, for Sadomba, have a symbiotic relationship, that is, they are interdependent $(2014,352)$. The spirit world, for Sadomba, comprises of animal spirits, human spirits, clan spirits as well as territorial spirits. These lesser spirits according to Sadomba report to Mwari who is the supreme spirit $(2014,352)$. While some of the spirits protect human beings and others are harmful to them, they all act in a variety of ways to guide and control human and societal behaviour $(2014,352)$.

Sadomba maintains that communication between the material and spiritual worlds is through mediums that include people, flora and fauna $(2104,353)$. What this suggests is that since the non-human world also participates in the sustenance of nature, it follows that this world has intrinsic value. For Sadomba, the spirit world and nature are more superior to human societies $(2014,353)$. Although Sadomba does not say it explicitly in this chapter, what I can discern from his argument is that the superiority of the spirit world to the human world gives the former the authority to reward good behaviour and punish errant behaviour.

Coming to the issue of land, Sadomba argues that land is strongly connected ogto the spirit world as it harbours infinite secrets and so it demands caution in

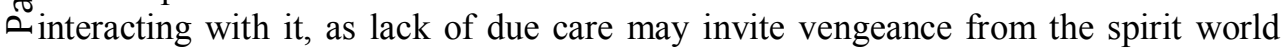
(SADOMBA 1998). By arguing that land is connected to the spirit world and by 
virtue of the fact that land provide food, shelter, clothes and life to all forms of existence; Sadomba, no doubt, acknowledges that this important asset has intrinsic value, just like the human being and the non-human being that is sustained by it as well as the sacred or ancestral sites that sit on land.

What gives sacred sites or ancestral sites intrinsic worth is that they are social spaces that link the dead with the living $(2014,355)$. In fact, the Shona believe that sacred sites like rocks, caves, mountains and rivers are places where territoria 1 spirits stay as they as they do their job of protecting the environment through the enforcement of moral codes of behaviour. Certain sanctions will befall those people who fail to revere these sacred sites. Many parents have had their children disappear as a result of failing to observe moral codes that guide and regulate behaviour during tours at these sites and recently a whiteman also disappeared after visiting mount Inyangani as a tourist.

Taringa and Mangena (2015) have looked at the importance of Shona Religion in defining the African environment focusing particularly on the behaviour of veterans of the armed struggle during the Second Chimurenga and also the behaviour of Zimbabweans during and after the Fast Track Land Reform Programme (FTLRP). This period is also known as the Third Chimurenga phase of Zimbabwe's struggle for total independence. Taringa and Mangena $(2015,42)$ argue that although Zimbabwe's liberation war was fought in the bush, veterans of the armed struggle respected both animal life and plant life. These veterans of the armed struggle respected the socio-religious rules and boundaries that were there in order to protect the interests of other species in the environment. In return, these species also respected these veterans of the armed struggle and they worked together to defeat the common enemy, the white coloniser (TARINGA and MANGENA 2015, 42).

Note of course, that Taringa and Mangena $(2015,43)$ did not only talk about animals and human beings' role in the consummation of the liberation struggle, they also talked about the importance of land itself as having given life to animals and vegetation as well as hiding places to these veterans of the armed struggle $(2015,43)$. Most importantly, for Taringa and Mangena, land was the abode of the ancestor spirits to whom people would pour libations from time to time in order to ask for spiritual guidance $(2015,43)$. While Taringa and Mangena did not directly make reference to the idea of deep ecology, their argument point to a different ve rsion of deep ecology that has a cultural and spiritual dimension.

Fast forward to the year 2001 when the FTLRP begins in earnest, one notices a paradigm shift in the attitudes of Zimbabweans who had benefitted from land re-distribution. Unlike the veterans of the armed struggle who respected land, animals and vegetation; beneficiaries of the FTLRP destroyed the environment with - reckless abandon. As Taringa and Mangena aver, the Third Chimurenga witnessed one of the worst chaotic periods on the environmental scene. Some lands and forests ogthat had been reserved as sacred in some communities fell victim to these land ¿hungry Zimbabweans $(2015,43)$. Many conservancies were intruded and animals were slaughtered at will as the powers of traditional leaders such as chiefs had been 
usurped by these land hungry elements $(2015,43)$. Shona Religion was used to justify this haphazard, chaotic and destructive approach to land re-distribution which left many animals and vegetation dead $(2015,43)$. Thus, all life forms and non-life forms were affected by these violent land invasions.

But what could explain this paradigm shift? Why were veterans of the armed struggle so respectful of the environment and its contents? Why were the beneficiaries of the FTLRP disrespectful of nature? These three questions have no easy answers. What is, however, probable is that this paradigm shift could have been a result of the colonial individual mentality that had been sown, among natives, as a result of the cross pollination of cultures, an attitude which was absent during the Second Chimurenga war. Thus, everyone wanted to have a piece of the cake and so the idea of collective and communal ownership of the land that had seen veterans of the armed struggle respecting land as the abode of the ancestors just disappeared. Colonialism had also resulted in the Christianization of the natives who no longer revered their ancestors as owners of the land.

Whichever way one may want to look at it and based on Taringa and Mangena's findings, the Shona environment has a different form of deep ecology which is onto-triadic as it involves the participation of the living, the living timeless and Mwari/Musikavanhu/Unkulunkulu (Creator God). This is totally different from the deep ecology that is enunciated by Næss, Devall and Sessions which is based on the idea of personal ethics and it only involves the participation of the living and has no invisible agent that ensures the implementation of policies required to build a sound and deep ecological ethic.

Having reviewed the above literature, what we can all see is that many forces are involved in ensuring that both the human world and the non-human world have intrinsic worth. It is not just left to human beings to decide whether or not the non-human world is worth respecting, the spirit world has a say as well. Most, importantly, the relationship between the human world and the non-human world is that of mutual interdependence. Below, I give a tabular summary of the dissimilarities between the idea of deep ecology in the West and the idea of deep ecology in African thought specifically in the Shona environment. 
Filosofia Theoretica: Journal of African Philosophy, Culture and Religions

Table 1: Deep Ecology in the West and Deep Ecology in the Shona Environment

A Summative Table

\begin{tabular}{|l|l|}
\hline Deep Ecology in the West & $\begin{array}{l}\text { Deep Ecology in the Shona } \\
\text { Environment }\end{array}$ \\
\hline $\begin{array}{l}\text { All life Forms have intrinsic value but } \\
\text { sometimes the non-human world has } \\
\text { instrumental value. }\end{array}$ & All life forms have intrinsic value \\
\hline $\begin{array}{l}\text { The non-human world should satisfy the } \\
\text { vital needs of the human world }\end{array}$ & $\begin{array}{l}\text { The non-human world and the } \\
\text { human world are mutually } \\
\text { dependent }\end{array}$ \\
\hline $\begin{array}{l}\text { Policy changes that ensure that the } \\
\text { interests and needs of all life forms are } \\
\text { safeguarded are not accompanied by } \\
\text { external forces that ensure the } \\
\text { implementation of the policies }\end{array}$ & $\begin{array}{l}\text { The spirit world ensures that policy } \\
\text { changes with regard to safeguarding } \\
\text { the interests and needs of the non- } \\
\text { human world are implemented. }\end{array}$ \\
\hline $\begin{array}{l}\text { Deep ecology is understood in the sense } \\
\text { of individual values }\end{array}$ & $\begin{array}{l}\text { Deep ecology is understood in the } \\
\text { sense of communal values }\end{array}$ \\
\hline $\begin{array}{l}\text { Only the human world has vital needs } \\
\text { that must be satisfied by the non-human } \\
\text { world }\end{array}$ & $\begin{array}{l}\text { Both the human world and the non- } \\
\text { human world have vital needs }\end{array}$ \\
\hline $\begin{array}{l}\text { Individual violations of the rights of } \\
\text { other life forms usually go unpunished. }\end{array}$ & $\begin{array}{l}\text { Violations of the rights of other life } \\
\text { forms are punishable by death, } \\
\text { misfortunes, droughts and bad luck. }\end{array}$ \\
\hline $\begin{array}{l}\text { The non-human world does not talk or } \\
\text { communicate and human beings act on } \\
\text { its behalf when certain moral codes are } \\
\text { violated }\end{array}$ & $\begin{array}{l}\text { The non-human world talks or } \\
\text { communicates and it acts without } \\
\text { the input of human beings when } \\
\text { certain moral codes are violated. }\end{array}$ \\
\hline
\end{tabular}




\section{Conclusion}

In this paper, I looked at the idea of deep ecology in terms of how it has responded to the dominant view in environmental ethics which considers nature or the environment to exist for the service of humanity. Proponents of deep ecology such as Næss, Devall and Sessions demonstrated the efficacy of deep ecology in challenging this somewhat dangerous position especially in the West. One of their chief arguments was that both the human world and the non-human world had intrinsic worth irrespective of the usefulness of the non-human world to the human world. I, however, heavily criticized Næss, Devall and Sessions for vacillating in their argument and for failing to take a clear position. At one point they seem committed in seeing an environment based on equality; at another time they still feel that the human world is more superior to the non-human world. In my attempt to answer the question: How applicable is the idea of deep ecology in the African context? I made the important observation that the idea of deep ecology in the West is different from the idea of deep ecology in Africa which is anchored on communitarian values and spirituality.

\section{Relevant Literature}

1. CALLICOT, J.B. "Animal Liberation: a triangular affair." [Environmental Ethics], 311-338, Winter 1980. Vol. 2 No. 4. E-Book.

2. COHEN, C. "The Case for the Use of Animals in Biomedical Research." [The New England Journal of Medicine], 865-870, March 1986. Vol. 315 No. 14. E-Book.

3. DEVALL, B and SESSIONS, G. [Deep Ecology, Living as if Nature Mattered]. 1985. Salt Lake City: Peregrine. Paperback.

4. HOLMES, Rolston III. "Environmental Ethics: Values in and Duties to the Natural World.' [The Broken Circle: Ecology, Economics and Ethics], F Hebert Bornmann and Stephen R Kellert eds., 1991. Yale University P ress: Yale. Paperback.

5. INFIELD, L. "A Translation of Immanuel Kant's Duties to Animals and Spirits." [Lectures on Ethics]. 1963. Harper and Row: New York. E-Book.

6. MACKINNON, B. [Ethics: Theory and Contemporary Issues]. 1998. Wordsworth Publishing Company: Belmont. Paperback. 
Filosofia Theoretica: Journal of African Philosophy, Culture and Religions

7. MANGENA, F. "Environmental Policy, Management and Ethics in Zimbabwe, 2000-2008." [Journal of Pan African Studies], 224-240, June 2014. Vol. 6 No.10. Paperback.

8. _. "Moral Status and the State of Creation Account: Critical Pro spects." [ZAMBEZIA: Journal of Humanities published by the University of Zimbabwe publications], 53-71, November 2012. Vol. 39 No. 2. Paperback.

9. MAPPES, T and ZEMBATY, J. [Social Ethics: Morality and Social Policy], 1997. McGraw-Hill: New York. Paperback.

10. CHEMHURU, M and MASAKA, D. “Taboos as sources of Shona People's Environmental Ethics." [Journal of Sustainable Development in Africa], 121-133, 2010. Vol. 12 No. 7. E-Journal.

11. MENKITI, I.A. "On the Normative Conception of a Person." In: [A Companion to African Philosophy], K Wiredu ed., 2006. Blackwell Publishing: Oxford. Paperback.

12. MUROVE, MF. "An African Commitment to Ecological Conservation: The Shona concepts of Ukama and Ubuntu." [The Mankind Quarterly], 195-215, 2007. Vol. 14 No. 2. E-Source

13. RAMOSE, M.B. [African Philosophy through Ubuntu], 1999. Mond Books: Harare. Paperback.

14. RUDEEN, M. "Ecology vs. Environment: What is the Difference?" [Available at http://www.examiner.com/article/ecology-vs-environment... Accessed 11 January 2015], 2009. Web.

15. SADOMBA, Z.W. "The Application of African Philosophy in Zimbabwe's Land Revolution." [Land: An Empowerment Asset for Africa: The Human Factor Perspective], CG Mararike ed., 2014. University of Zimbabwe Publications: Harare. Paperback

16. _ [Using Taboos and Proverbs as Oral Archives of Indigenous Knowledge, Unpublished MSc course reader], 1998. Wageningen University: Netherlands. E-Book

17. TARINGA, N and MANGENA, F. "Shona Religion in Zimbabwe's Land Reform Program: Is a Shona Ecological Ethic Possible?" [Philosophy in African Traditions and Cultures], F Mangena, TA Chimuka and F Mabiri 
eds., 2015. Washington, DC: The Council for Research in Values and Philosophy: Washington, DC. Paperback.

18. TARINGA, N. "Animals as First Class Citizens." [Land: An Empowerment Asset for Africa: The Human Factor Perspective], CG Mararike ed., 2014. University of Zimbabwe Publications: Harare. Paperback. 